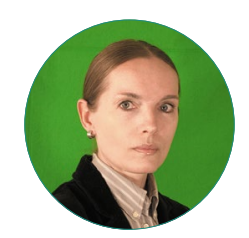

Н. В. Колесник

\title{
ГЕНДЕРНОЕ (НЕ)РАВЕНСТВО В ПОЛИТИЧЕСКОЙ ВЛАСТИ РОССИЙСКИХ РЕГИОНОВ
}

\section{Правильная ссылка на статью:}

Колесник Н. В. Гендерное (не)равенство в политической власти российских регионов // Мониторинг общественного мнения: экономические и социальные перемены. 2021. № 4. C. 468-491. https://doi.org/10.14515/monitoring.2021.4.1652.

\section{For citation:}

Kolesnik N. V. (2021) Gender (In)Equality in the Political Power of Russian Regions. Monitoring of Public Opinion: Economic and Social Changes. No. 4. P. 468-491. https://doi.org/10.14515/ monitoring.2021.4.1652. (In Russ.) 
ГЕНДЕРНОЕ (НЕ)РАВЕНСТВО В ПОЛИТИЧЕСКОЙ ВЛАСТИ РОССИЙСКИХ РЕГИОНОВ

КОЛЕСНИК Наталья Владимировна - кандидат социологических наук, ученый секретарь, Социологический институт РАН - филиал ФНИСЦ РАН, Санкт-Петербург, Россия

E-MAIL:knv96@yandex.ru

https://orcid.org/0000-0003-2323-6799

Аннотация. Статья посвящена проблеме гендерного (не)равенства в политической элите российских регионов. В первой части работы разбирается научная дискуссия относительно гендерного профиля политической власти. В частности, рассматриваются исследовательские подходы по поводу участия женщин в политическом процессе как в России, так и в зарубежных странах. В статье определено, что формирование политической элиты на региональном уровне не завершено в силу того, что в обществе продолжаются социально-политические трансформации и гендерный профиль власти находится в динамичном состоянии.

Во второй части работы представлены результаты эмпирического исследования карьерных траекторий и образовательного уровня политической элиты десяти российских регионов (Москва, Санкт-Петербург, Ленинградская, Костромская, Калининградская, Новосибирская и Ростовская области, Республика Дагестан, Хабаровский и Ставропольский края). Структурно-биографический анализ (649 биографий депутатов) позволил выявить гендерную специфику парламентов в исследуемых российских регионах. Согласно полученным данным, несмотря на то что женщины
GENDER (IN)EQUALITY IN THE POLITICAL POWER OF RUSSIAN REGIONS

Natalya V. KOLESNIK ${ }^{1}$ - Cand. Sci. (Soc.), Academic Secretary

E-MAIL:knv96@yandex.ru

https://orcid.org/0000-0003-2323-6799

\footnotetext{
${ }^{1}$ Sociological Institute of FCTAS RAS, Saint Petersburg, Russia
}

Abstract. The article focuses on the problem of gender (in)equality in the political elite of Russian regions. In the first part of the paper, we analyze the academic discussion on the gender profile of power. We review methodological approaches to the analysis of women's participation in politics in Russia and foreign countries. We conclude that in Russia, the formation of political elite at a regional level has not been completed. This is caused by continuing socio-political transformations in the society as well as a dynamic state of the power gender profile.

In the second part of the article, we represent results of our study on career trajectories and educational level of the political elite in ten Russian regions (Moscow and St. Petersburg, Leningrad, Kostroma, Kaliningrad, Novosibirsk and Rostov regions, the Republic of Dagestan, Khabarovsk and Stavropol regions). Based on biographical analysis (649 biographies of deputies) we identified the gender specificity of parliaments in studied territories of Russia. According to the data, although women are accepted in the structures of power, the political elite is reproduced on closed grounds. We found that the entry of women into a regional parliament is never accidental 
"допускаются" во властные структуры, все же политическая элита воспроизводится на закрытых основаниях. Чаще всего попадание женщин в региональный парламент носит неслучайный характер и продолжает ее профессиональную траекторию (административную, партийную, экономическую). Наблюдается устойчивый процесс горизонтального перемещения с одной элитной позиции на другую. Показано, что в рассматриваемых регионах происходит профессионализация политической элиты и формируется пул политиков, в который входят и женщины-депутаты.

Даже в том случае, когда в парламентскую элиту попадает относительно значимое число женщин (от $30 \%$ и выше), открытой конкуренции за место в парламенте между кандидатами в депутаты не происходит и гендерный профиль российской власти радикально не изменяется. В целом сохраняется старый гендерный порядок внутри российской политической элиты, которая преимущественно воспроизводится по типу квазициркуляции (в терминологии Д. Хигли). При этом политическая элита активно профессионализируется, переплетается с административной элитой и оказывается социально закрытой для притока новых персон.

Ключевые слова: гендер, элита, воспроизводство, социальный институт, российские регионы but continues their professional trajectory (administrative, party-line, economic). Thus, the women are involved into a sustainable horizontal movement from one elite position to another. We show that in the regions under consideration a professional political elite which includes female deputies has been forming.

Even when a relatively significant number of women (30\% and more) get into the parliamentary elite, there is no open competition between candidates for deputies, and the gender profile of the Russian government does not radically change. Within the Russian political elite, the old gender order remains, which is reproduced according to the type of quasi-circulation (in D. Higley's terminology). At the same time, the political elite is actively professionalizing, intertwining with the administrative elite, and is enclosed to the influx of new people.

Keywords: gender, elite, reproduction, gender order, social institution, Russian regions 


\section{Введение}

В глобальном рейтинге Global Gender Gap по индексу "гендерного паритета» в 2017 г. Россия занимала 71 место среди 144 стран (для сравнения в 2006 г.44 место). Для расчета глобального индекса учитываются такие показатели, как участие и возможности женщин в политической, экономической сфере, уровень здоровья, доступ к образованию. Анализ показывает, что самые большие разрывы в данных между мужчинами и женщинами в мире наблюдаются именно в политической сфере. По индексу участия в политике российские женщины в 2017 г. занимали 108 место из 144 возможных: в российском парламенте было 105 женщин, 113 женщин занимали позиции в министерствах. За период с 2006 г. положение России по этому индексу в глобальном рейтинге улучшилось на 13 пунктов, и страна переместилась со 121 места в 2006 г. на 108 место в 2017 г. $^{1}$ При этом по уровню экономического участия (занятость и размер оплаты труда) в 2017 г. у российских женщин были более прочные позиции (21 место в 2017 г. и 44 место - в 2006 г.). Для сравнения: в 2018 г. в первую десятку рейтинга гендерного равенства входили Исландия, Норвегия, Швеция, Финляндия, Никарагуа, Руанда, Намибия, Филиппины, Новая Зеландия, Ирландия ${ }^{2}$.

Как и в прошлом веке, большая российская политика по-прежнему не имеет женского лица, даже несмотря на то, что некоторые ключевые позиции на федеральном и региональном властном уровне занимают женщины (например, В.И. Матвиенко, Т. А. Голикова, О. Ю. Голодец, Э. А. Памфилова и др.) ${ }^{3}$. Эмпирические данные по участию российских женщин в политике демонстрируют, что показатель представленности женщин во властных структурах в постсоветский период снижается из года в год. Так, исследование Н. Л. Пушкаревой показывает, что в числе депутатов Государственной думы первого созыва (1993-1995 гг.) было 13,6\% женщин, второго созыва (1995-1999 гг.) - 10\%, третьего созыва (1999-2003 г.) - только 7,7\% (для сравнения, в составе верхней палаты парламента в 2001 г. была одна женщина, а в 2002 г._-семь) [Пушкарева, 2008: 120]. При этом следует согласиться с мнением исследователей, что «апелляция к количественным показателям фактически сводит вопрос о женщинах как субъектах гендерной политики к простой арифметике: чем больше женщин-руководителей, тем больше гендерного равенства" [Середа, 2011: 94]. По мнению М.В.Середы, за таким статистическим пониманием гендерного равенства, которое доминирует в публичном и активистском дискурсе, скрывается допущение, "что все женщины обладают разделенным социальным опытом, обусловленным их „сущностью“ / гендерным порядком / структурой занятости, что способствует агрегированию различных интересов и формированию консолидированной позиции, включающей по умолчанию требование женской эмансипации" [там же: 94-95].

\footnotetext{
1 The Global Gender Gap Report//World Economic Forum. 2017. November 2. URL: https://www.weforum.org/reports/ the-global-gender-gap-report-2017 (дата обращения: 01.03.2020).

2 Global Gender Gap Report//World Economic Forum. 2018. URL: https://reports.weforum.org/global-gender-gapreport-2018/ (дата обращения: 01.03.2020).

3 В.И. Матвиенко - председатель Совета Федерации Федерального Собрания РФ, Т. А. Голикова - заместитель председателя правительства РФ, О. Ю. Голодец-заместитель председателя правительства РФ (до 15 января 2020 г.), Э. А. Памфилова - председатель циК РФ.
} 
Старый гендерный порядок воспроизводится в большинстве действующих социальных и политических институций, что неизбежно находит отражение в массовом сознании россиян. Если обратиться к результатам опросов общественного мнения, то в оценках российского гендерного порядка наблюдается устойчивое мнение, что в современном российском обществе не существует полного равенства в правах и обязанностях мужчин и женщин ${ }^{4}$. По результатам исследований, $62 \%$ наших соотечественников считают, что российскому обществу необходимо стремиться к полному равенству прав мужчин и женщин, но только чуть более трети опрошенных выразили уверенность, что полное равенство прав возможно (45\% мужчин и $33 \%$ женщин), и $59 \%$ россиян утверждают, что нужно стремиться к полному равенству обязанностей мужчин и женщин ${ }^{5}$.

\section{Академические дискуссии о гендерном равенстве}

В академическом дискурсе фиксируется активное обсуждение вопросов гендерного равенства. Рассмотрим основные дискуссионные точки в российской и зарубежной науке. Введение гендера как аналитического инструмента и концепта в научный оборот обусловлено, прежде всего, важностью изучения проблематики гендерных различий и гендерных неравенств. В работах российских исследователей С. Г. Айвазовой, Е. А. Здравомысловой, А. А. Темкиной, О.Г. Овчаровой, Н. А. Шведовой, Г. Г. Силласте, И. Н. Тартаковской, О.А. Хасбулатовой и др. авторов освещаются вопросы гендерного дисбаланса и гендерной асимметрии в политике и экономике, специфики участия женщин в политической жизни (см. [Айвазова, 2012; Здравомыслова, Темкина, 2003, 2007; Овчарова, 2007; Шведова, 2003; Силласте, 1994; Тартаковская, 2015, 2017; Хасбулатова, 2014]). Имеющиеся работы служат примером осознания важности гендерной проблематики в анализе власти и политических институций в контексте демократической перспективы и затрагивают аспекты степени влияния пола как фактора развития политической системы. Чаще всего подобные работы имеют междисциплинарный характер и представляют значимый для исследуемой нами проблематики анализ.

По нашему мнению, при исследовании гендерного вопроса необходимр включение и рассмотрение понятия "гендерный порядок". Российские социологи Е. А. Здравомыслова и А. А. Темкина определяют “гендерный порядок" как "систему неравенства и дифференциации, связанную с позициями разных групп мужчин и женщин в разных сферах экономики, политики и частной жизни. Гендерные отношения регулируются определенными правилами, существуют устойчивые, но подвергающиеся изменениям механизмы воспроизводства гендера" [Здравомыслова, Темкина, 2003: 300-301]. Анализируя гендерный порядок в советском обществе, исследователи приходят к выводу, что этот порядок был этакратическим и патримониальным, в нем сталкивались, сосуществовали старые и новые гендерные уклады [там же: 320].

Обращаясь к вопросам гендерного неравенства в современной России, исследователи, как правило, отмечают, что социально-экономическое положение жен-

\footnotetext{
4 Гендерное равенство в России: идеал или ложная цель? (аналитический обзор) // ВЦИОМ. 2019. 20 марта. URL: https://wciom.ru/index.php?id=236\&uid=9601/ (дата обращения: 12.12.2019).

5 Там же.
} 
щин ухудшается, они вытесняются из сферы принятия решений, феминизируется бедность [Гнедаш, 2007]. По мнению Н. Л. Пушкаревой, которая анализировала представительство женщин и мужчин в органах государственной власти, там, где больше власти,- меньше женщин [Пушкарева, 2008]. Основной посыл работы Н.Л. Пушкаревой состоит в том, что «модернизация гендерной системы происходит на основе традиционной патриархальной концепции, постольку гендер продолжает рассматриваться через призму репродуктивно-биологических функций полов" [там же: 119]. Анализируя составы правительств, исследователь обращает внимание на то, что в "рассматриваемый период (1991-2006) в Российской Федерации в составе действующего правительства не было женщин. Женщин не было и нет среди руководителей республик, мэров крупнейших городов. Среди губернаторов, глав национальных автономий женщин нет. Нет ни одной женщины в Совете Безопасности. Примерно в трети регионов женщин вообще нет в законодательных собраниях" [там же: 122] 6 . По мнению автора, в обществе сложилась противоречивая ситуация, когда идеология равенства не отрицается, однако право быть избранной в реальной политической жизни для женщин практически отсутствует.

Во второй половине 1990-х годов появились исследования, в которых не только содержатся описание и анализ той или иной субэлитной группы, но и вводится новое измерение элиты - гендерное [Колесник, 2009]. Практически первыми в рамках российской элитологии предприняли попытку обозначить проблему "стеклянного потолка" Н. Ю. Лапина и А. Е. Чирикова, когда в 2008 г. провели сравнительное исследование о женщинах на высших этажах власти в России и Франции [Чирикова, Лапина, 2009]. На примере Франции и двух российских регионов (Тамбовская область и Пермский край), используя преимущества техники глубинного интервью, авторы определили три модели продвижения женщин во власть во Франции и в России [там же]:

1) модель постепенного роста,

2) модель парашютирования (привлечение кандидатов во власть извне) и

3) модель наследования (характерна только для Франции).

Российские элитологи полагают, что центральную роль в “открытии" представительных органов власти для женщин во Франции сыграли политические акторы - партии, в частности Французская социалистическая партия (ФСП), которая одной из первых приняла решение закрепить на парламентских выборах $28 \%$ одномандатных округов за кандидатами-женщинами [там же: 17].

Иной подход к вопросу о формировании политической элиты предлагают исследователи в рамках теории рационального выбора, которая до недавнего времени была относительно популярна при объяснении процесса рекрутирования в американские законодательные органы. Сторонники данного подхода предполагают, что баллотирование кандидатов на различные должности происходит только в том случае, если имеются соответствующие возможности. По мнению П. Норрис

\footnotetext{
${ }^{6}$ В целом разделяя точку зрения Н.Л. Пушкаревой по поводу гендерного равенства в современной России, следует отметить некоторую неточность в том, что в период 1991-2006 гг. в составе российского правительства женщины не были представлены. Известно, что в 1990-е годы высшие позиции в правительстве занимали, например, И.И. Гребешева (вице-премьер правительства РФ), Э.А. Памфилова (министр социальной защиты РФ), Л. Ф. Безлепкина (министр социальной защиты РФ), Т.Б. Дмитриева (министр здравоохранения РФ), Н. Л. Дементьева (министр культуры РФ), О.Г. Дмитриева (министр труда и социального развития РФ) и др.
} 
и Д. Ловендуски, эти возможности определяются институциональной и политической ситуацией, особенностями структуры выборных должностей и правилами, определяющими способ их достижения. Далее авторы исследования обращают внимание на роль партий, количество выборных должностей на разных уровнях, текучесть кадров и степень партийной конкуренции в каждом штате и приходят к выводу, что указанные возможности различаются от штата к штату, от одного города к другому [Norris, Lovenduski, 2004: 21].

По мнению Р. Инглхарта и П. Норрис, основанием для роста гендерного равенства выступают культурные ценности, неизбежно влияющие на трансформацию традиционных представлений о роли мужчины и женщины. В первую очередь культурные ценности изменяются под влиянием модернизации, при переходе того или иного общества от аграрного к индустриальному и далее - от индустриального к постиндустриальному обществу [Inglehart, Norris, 2010]. Предложенная американскими учеными классификация обществ и государств показывает устойчивые взаимозависимости типа общества и уровня демократии: чем выше степень экономического развития, тем демократичнее государство [там же: 24]. При этом, используя данные по семидесяти странам мира, авторы исследования показывают вариации и корреляции между ростом гендерного равенства и богатством/ бедностью общества, молодым и старым поколениями. Особое внимание в их работе уделено гендерному измерению политического участия: традиционный активизм через выборы и политические партии, гражданский активизм через общественные организации, движения и протестный активизм (петиции, бойкоты, демонстрации). Что касается гендерного равенства в элите, то авторы заключают, что в мире сохраняется мужское доминирование в традиционных политических элитах, таких как партии и парламенты [там же: 28].

Таким образом, анализ научной литературы показывает, что в большинстве случаев авторы исследований по участию российских женщин в политике и выстраиванию их карьерных траекторий в политических институциях подчеркивают, что подобные практики носят аномальный характер. Существующие эмпирические исследования по гендерной асимметрии в российской политической системе создают “замкнутый объяснительный круг», когда институциональный порядок выступает основанием для исключения женщины из большой политики и незначительного присутствия женщин в малой политике (на уровне муниципальных и иных локальных органов власти). Основная исследовательская проблема заключается в том, чтобы выявить особенности гендерного (не)равенства в политической элите в российских регионах ${ }^{7}$. В первую очередь работа нацелена на анализ специфики профессионального и образовательного профиля политической элиты рассматриваемых регионов через призму гендерной оптики.

\section{Методический инструментарий}

Европейские исследователи Г. Бест и Д. Хигли обращают внимание на то, что изучение истории возникновения и социально-демографических характеристик политической элиты (социальное происхождение, возраст, пол, образование

\footnotetext{
7 В рамках исследования для идентификации политической элиты применяется позиционный подход, в соответствии с которым к ней отнесены депутаты региональных и федерального парламентов.
} 
и карьера) считается доминирующим подходом в современной элитологии в силу доступности биографических данных [Best, Higley, 2018: 4]. С начала 1980-х годов ситуация в элитологии изменилась в силу цифровизации данных, возможности привлечения статистических методов и других достижений в области коммуникаций, которые позволили понять политические взгляды элиты, специфику межличностных сетей, практики процесса принятия решений. В этой связи, замечают Г. Бест и Д. Хигли, "исследования политических элит стали гораздо более многогранными и сосредоточены на том, что делают элиты, а не на том, откуда они берутся" [ibid.].

В этом смысле структурно-биографический метод, который нами используется, обладает рядом преимуществ и расширяет возможности в изучении такой закрытой социальной общности, как элита вообще и политическая элита в частности. Структурно-биографический метод сочетает в себе преимущества как формализованной "официальной биографии", так и возможность дополнить эту биографию "качественной" информацией из различных источников (в том числе и интервью в СМИ). Эмпирической основой исследования послужили объединенные в одно целое данные 649 биографий региональных депутатов. В среднем каждая биография занимает три-четыре страницы файла в формате MS Word, иногда текстовый объем одной биографии превышает десять страниц (общий объем данных более 2500 страниц). На первом этапе работы биографические сведения по каждому депутату были введены в анкету, в которой содержатся переменные, отражающие основные социальные характеристики элиты. Информация для анкеты была собрана из открытых источников - официальные сайты региональных парламентов и других органов власти, социальные сети, СМИ и др. Если в биографии того или иного депутата встречались противоречивые фактологические данные, мы привлекали дополнительные источники информации либо вообще не учитывали такие сведения при обработке анкеты. На втором этапе работы все биографические данные были закодированы и обработаны с использованием статистического пакета SPSS. Полученная количественная информация в каждом из десяти исследуемых регионов полностью охватывает (до $100 \%$ ) депутатский корпус, считающийся важным сегментом политической элиты. В базе данных представлены биографии депутатов региональных парламентов (2016-2021 гг.), депутатов Государственной думы РФ седьмого созыва, избранных от регионов и представителей регионов в Совете Федерации РФ, что в целом позволяет определить основные тренды в особенностях функционирования региональной политической элиты.

Региональная политическая элита представлена десятью субъектами РФ: Москва, Санкт-Петербург, Ленинградская, Костромская, Калининградская, Новосибирская и Ростовская области, Республика Дагестан, Хабаровский и Ставропольский края. Отбор регионов осуществлялся по принципу “взаимодополнения", когда в выборке присутствуют северные и южные, бедные и богатые, центральные и приграничные, малые и крупные российские территории.

Итак, кто представляет политическую элиту? Данный вопрос относится к числу дискуссионных, начиная с позапрошлого века, когда попытки по его осмыслению предпринимали основоположники элитизма в лице Г. Моска, В. Парето и Р. Михельса. В более поздних исследованиях зарубежных ученых фиксируется, что элиты и элитные структуры как таковые (и политические в том числе) в условиях 
изменения социального и политического порядка неизбежно трансформируются и адаптируются к общественным изменениям. Исследователи Г. Бест и Д. Хигли формулируют, что политическую элиту представляют как отдельные лица, так и небольшие и относительно сплоченные группы, обладающие властью на национальном и наднациональном уровнях:

Политические элиты включают в себя знакомый триумвират "властной элиты", состоящий из ведущих бизнесменов, правительственных чиновников и военных лидеров <...>, а также лиц и групп, занимающих стратегические позиции в политических партиях и парламентах, крупных общественных организациях и профессиональных ассоциациях, важных медиакомпаниях и профсоюзах, религиозных и других иерархически структурированных институтах, достаточно сильных, чтобы влиять на процесс принятия политических решений. [Best, Higley, 2018: 3]

В нашем исследовании "политическая элита" определяется в рамках позиционного подхода, принятого в современной элитологии (более подробно о существующих подходах см. [Дука, 2015]). Согласно этому подходу, к элите относятся те, кто занимает высшие позиции в той или иной институции. Представители депутатского корпуса выступают одним из значимых сегментов политической элиты, однако далеко не единственным. Традиционно к политической элите относят лидеров партий, профессиональных, общественных, религиозных организаций, медиахолдингов и др. В этом смысле представители административной элиты - министры, руководители исполнительных органов власти - исследуемых регионов, несмотря на активные практики взаимодействия с политической элитой и их относительную зависимость друг от друга, не рассматривалась нами в качестве самостоятельного объекта исследования.

\section{Результаты исследования}

Общие характеристики региональной политической элиты

Прежде чем рассмотреть типичные карьерные траектории женщин в политике, проанализируем общие социально-демографические характеристики политической элиты десяти регионов. Сами по себе данные о доминировании мужчин в депутатском корпусе имеют малое отношение к прояснению гендерной проблематики, но тем не менее эти сведения показывают, что в десяти парламентах рассматриваемых регионов $85 \%$ депутатских мандатов принадлежат мужчинам и только $15 \%$ - женщинам (см. табл. 1). Среди мужчин преобладает возрастная когорта 51-60 лет (каждый третий депутат), женщины обретают мандат депутата чаще всего в этом же возрастном диапазоне. Обращает на себя внимание крайне малое количество молодых депутатов в политической элите десяти российских регионов (8\%) и преобладание тех, кто относится к средней и старшей возрастной группе (от 40 лет и выше). На долю лиц предпенсионного возраста приходится примерно одинаковое число женщин и мужчин (35\% и $29 \%$ соответственно). Анализ возрастных различий через гендерную призму показывает, что, несмотря на доминирование мужчин в региональных парламентах, в возрастных когортах наблюдается относительный гендерный паритет. 
Таблица 1. Пол и возрастные когорты в политической элите, 2019 г.

\begin{tabular}{|c|c|c|c|c|}
\hline \multirow{2}{*}{$\begin{array}{c}\text { Возрастные } \\
\text { когорты }\end{array}$} & \multicolumn{4}{|c|}{ Пол } \\
\cline { 2 - 5 } & $\mathbf{2}$ & $\%$ & $\mathbf{N}$ & Женский \\
\hline $21-30$ & 5 & 0,9 & 3 & 3 \\
\hline $31-40$ & 63 & 11 & 6 & 6 \\
\hline $41-50$ & 146 & 26 & 22 & 22 \\
\hline $51-60$ & 181 & 32 & 35 & 35 \\
\hline $61-70$ & 135 & 24 & 27 & 27 \\
\hline $71-85$ & 28 & 5 & 8 & 8 \\
\hline Всего & 558 & 85 & 101 & 15 \\
\hline
\end{tabular}

Поскольку возраст и принадлежность к "политическим поколениям" относительно взаимосвязаны, то и в случае различения последних наблюдается гендерное равенство (см. табл. 2). Видно, что в общем массиве данных как среди мужчин, так и среди женщин преобладают “политическое поколение застоя" (1953-1964 года рождения) и "политическое поколение кризиса" (1972-1990 года рождения). Среди представителей «поколения застоя" мужчин чуть больше (39\%), чем женщин (36\%), среди "поколения кризиса" - $29 \%$ мужчин и $24 \%$ женщин соответственно (см. табл. 2). Анализ представителей законодательной власти в разрезе «политических поколений" показывает, что очевидны взаимосвязи между радикальными трансформациями в обществе и изменениями в характере профессиональных карьер. Определено, что в профессиональных карьерах депутатов "поколения застоя", как правило, наблюдается постепенное восхождение по карьерной лестнице, когда человек преодолевает ступеньку за ступенькой в рамках одной институции на протяжении своей жизни, практически не меняя сферы деятельности. В биографиях же депутатов "поколения кризиса и начала перестройки" наблюдается иная картина, и чаще всего фиксируются частые перемещения из одной профессиональной сферы в другую.

Таблица 2. Пол и политические поколения в политической элите, 2019 г.

\begin{tabular}{|c|c|c|c|c|}
\hline \multirow{2}{*}{$\begin{array}{c}\text { Политические поколения / } \\
\text { год рождения }\end{array}$} & \multicolumn{3}{|c|}{ Пол } \\
\cline { 2 - 5 } & $\mathbf{N}$ & $\%$ & $\mathbf{N}$ & $\%$ \\
\hline $\begin{array}{c}\text { Военное поколение } \\
(1919-1933)\end{array}$ & 1 & 0,2 & 0 & 0 \\
\hline $\begin{array}{c}\text { Поколение оттепели } \\
\text { (1934-1952) }\end{array}$ & 67 & 12 & 19 & 19 \\
\hline $\begin{array}{c}\text { Поколение застоя } \\
\text { (1953-1964) }\end{array}$ & 106 & 19 & 22 & 22 \\
\hline $\begin{array}{c}\text { Поколение кризиса } \\
(1972-1990)\end{array}$ & 161 & 29 & 24 & 24 \\
\hline Всего & 550 & 85 & 101 & 15 \\
\hline
\end{tabular}


При рассмотрении общих социально-демографических характеристик региональных парламентов стоит также обратить внимание и на правовой статус депутатов, например, в части возраста (предельный возраст без ограничений), личностных характеристик, профессиональной основы. В российской правовой практике не существует строгих ограничений по тому, с какого возраста можно баллотироваться в региональные депутаты, не установлен и предельно допустимый возраст для получения депутатского мандата. Например, решение по этому вопросу относится к прерогативе региональных парламентов, которые по-разному решают этот вопрос (с 18, 19, 20 лет и отсутствует предельный возраст). Если не существует предельных ограничений по возрасту, то не удивительно, что в общем массиве депутатского корпуса десяти регионов преобладают (среди как мужчин, так и женщин) представители среднего (41-60 лет) и старшего возрастов (от 60 лет и выше). Больше всего пенсионеров зафиксировано в парламентах Москвы, Санкт-Петербурга и Новосибирской области. Самый молодой депутат, которому на момент избрания был 21 год, работает в парламенте Санкт-Петербурга.

Оказывает влияние на социальные характеристики депутатов и такой внешний фактор, как тип избирательной системы. Как отмечают исследователи, при пропорциональной избирательной системе отбор кандидата на депутатский пост определяется не личностью кандидата, а авторитетом партии, от которой он выдвигается [Фомичева, 2014]. Согласно федеральному закону, особенностью формирования региональных законодательных собраний является то, что не существует обязательного порядка исполнения депутатом своих обязанностей. Это означает, что депутаты могут работать как в парламенте, так и на прежней работе (на постоянной основе $)^{8}$. В современной России есть только два региональных профессиональных парламента (в Санкт-Петербурге и Чеченской республике), где депутаты состоят в штате законодательного органа власти. В других российских регионах вопрос о том, совмещать ли законодательную деятельность депутату с иной работой или нет, решается дифференцировано. Например, случай парламента Калининградской области показывает, что не более 22 депутатов из 40 могут профессионально совмещать парламентскую и другие виды деятельности ${ }^{9}$. Региональные законы определяют так называемые квоты для «профессиональных" депутатов, что оказывается объективным механизмом сдерживания процесса профессионализации политической элиты, когда депутатский корпус воспроизводится на закрытых основаниях. С другой стороны, эмпирические данные показывают, что “ядро" профессиональных депутатов, заседающих в парламентах от созыва к созыву, относительно устойчиво. Согласно данным по десяти российским регионам на 2019 г., впервые заняли региональное парламентское кресло $61 \%$ депутатов, меньше всего обновился дагестанский парламент - там лишь $42 \%$ депутатов впервые обрели мандат.

\footnotetext{
8 Федеральный закон от 06.10.2003 № 131-Ф3 (ред. от 20.07.2020) «Об общих принципах организации местного самоуправления в Российской Федерации" (с изм. и доп., вступ. в силу с 28.08.2020).

9 «В случае если деятельность депутата областной Думы осуществляется на профессиональной постоянной основе, указанный депутат областной Думы не может заниматься другой оплачиваемой деятельностью, кроме преподавательской, научной и иной творческой деятельности, если иное не предусмотрено законодательством Российской Федерации" (см.: Закон "О статусе депутата Калининградской областной Думы" // Калининградская областная Дума. 1995. 18 сентября. URL: https://duma39.ru/duma/credentials/statuslaw.php (дата обращения: 24.08.2021)).
} 
В целом при оценке гендерных диспропорций в региональных парламентах следует отметить, что самыми феминизированными из исследованных нами легислатур оказались московский парламент (40\% женщин) и парламент Хабаровского края (32\%), где более $30 \%$ депутатских мандатов имеют женщины ${ }^{10}$. Первичный анализ данных показывает, что в большинстве российских регионов существует гендерная диспропорция в политической элите. Так происходило и в более ранний период постсоветской истории, когда в законодательных собраниях РФ было не больше $9 \%$ женщин: «например, в законодательных собраниях Новосибирской, Челябинской областей женщин вообще не было. Правда, в законодательном собрании Республики Карелия в числе депутатов было тогда $32 \%$ женщин. Но со временем эти проценты снизились, и лишь в составе Московской городской думы в 2003 г. их было около 23\%" [Пушкарева, 2008: 120]. Что касается федерального уровня управления в РФ, то и здесь работает принцип «чем выше уровень власти, тем меньше женщин".

\section{Карьерные траектории}

При изучении гендерных аспектов в карьерных и жизненных траекториях политической элиты необходимо учитывать не только ее внутренние характеристики, но и социальный контекст, ибо он актуализирует и дифференцирует происходящее. Методологически важно для прояснения вопроса о карьерах и жизненных путях представителей политической элиты включение как количественных, так и качественных данных. Очевидно, что для перспективы исследования карьерных и жизненных траекторий депутатов интерес представляют события в биографии индивида, являющиеся одновременно результатом свершившегося перехода от “структуры без агентности" к "агентности внутри структуры" [Блоссфельд, Хъюнинк, 2006], то есть социальная мобильность. Как отмечают Х.-П. Блоссфельд и И. Хъюнинк, в исследованиях жизненного пути подчеркивается, что общественные структуры и институты напрямую связаны с уровнем индивидуального действия. В свою очередь, действия и поведение индивидов, объединенные социальными сетями, неизбежно влияют на изменение социальных и институциональных структур общества [там же]. Согласно подходу К. Майера, социальное происхождение, образование, профессиональная подготовка и начало трудовой жизни считаются главными факторами, определяющими индивидуальные биографии, поэтому они оцениваются как "социальные структуры жизненного пути" [там же: 16].

Эмпирические данные по депутатскому корпусу десяти российских регионов позволяют определить узловые моменты, точки перехода и начало профессиональной карьеры в жизненных путях представителей политической элиты. Профессиональная карьера составляет часть многомерного жизненного пути индивида и оказывает влияние на другие сферы его жизни, одновременно находясь в зависимости от них. Так, гендерный анализ биографий региональных

\footnotetext{
10 Гендерные квоты получили распространение в мире после принятия Пекинской декларации и Платформы действий в 1995 г. на четвертой Всемирной конференции по положению женщин, где были провозглашены равные права для мужчин и женщин. Основная идея гендерных квот состоит в увеличении политического представительства женщин, в том числе и в парламентах. Для формирования некой критической массы женщины должны занимать от $30 \%$ до $40 \%$ мест.
} 
депутатов показывает, что в зависимости от возраста среди мужчин и женщин наблюдается асимметрия при их вхождении в элиту. Женщины впервые гораздо позже занимают элитную позицию, чем мужчины. В молодой когорте региональных депутатов (от 18 до 40 лет) представлены 63\% мужчин и 41\% женщин, в группе среднего возраста наблюдается 55\% женщин и $36 \%$ мужчин. Женщины достигают высоких позиций во властных иерархиях в среднем в более позднем возрасте. Это, вероятнее всего, показывает, что при планировании женщинами профессиональной траектории на первый план выходят иные аспекты жизненного сценария (возможно, что семья, брак). В этом смысле уместно вспомнить о биологических причинах низкой представленности женщин в большой политике. Сторонники биологического подхода считают, что “женщина сама ответственна за низкое участие в политике, поскольку у нее якобы не только отсутствует желание, но и происходит „естественное смещение“ интересов в область семейно-бытовых отношений, в частную/приватную сферу" [Колесник, 2009: 79].

Другое объяснение связано с тем, что на планирование профессиональной карьеры структурирующее влияние оказывают институции, в которых занята женщина. Исследования российских социологов А. Е. Чириковой и Н. Ю. Лапиной по женской элите показывают, что во Франции основным каналом для рекрутирования женщин в политическую элиту выступают структуры гражданского общества. По их мнению, если и будет происходить вовлечение французских женщин в большую политику, то это «будет, как и в прошлом, результатом комбинации различных факторов: борьбы самих женщин за свои права; модернизации общества и обновления его политических и экономических институтов. Все чаще женщины, представляющие гражданское общество, будут делать карьеру, медленно поднимаясь с низового уровня вверх по карьерной лестнице. В России складывается иная ситуация" [Чирикова, Лапина, 2009: 71-72].

В числе переменных, связанных с профессиональной деятельностью депутатов, есть такая как "номер элитной должности в биографии", позволяющая оценить не только степень профессионализации политической элиты, но количество новых депутатов в региональном парламенте в гендерном измерении. Данная переменная позволяет охарактеризовать обновляемость депутатского корпуса десяти российских регионов (см. табл. 3). Впервые занимают позицию депутата почти половина мужчин (50\%) и больше половины женщин (66\%). Во второй раз были избраны $22 \%$ мужчин и $21 \%$ женщин из всей депутатской общности исследуемых регионов. Среди тех, кто получил мандат регионального депутата в третий раз, женщин в три раза меньше, чем мужчин (14\% мужчин-депутатов и 4\% женщиндепутатов), а среди тех, для кого законодательная работа является профессией,$14 \%$ мужчин и $9 \%$ женщин.

Если суммировать эти данные, то получится, что $50 \%$ мужчин и $33 \%$ женщин избирались в парламенты более чем два раза. Это подтверждает гипотезу о том, что и в условиях профессионализации региональных парламентов сохраняется гендерное неравенство. При оценке гендерной дифференциации в десяти региональных парламентах через призму профессионализации элиты следует отметить, что статус профессионального депутата (тот, кто избирался более одного раза) среди мужчин имеют почти половина (244 из 482), а среди женщин — почти в во- 
семь раз меньше (32 женщины из 95). Таким образом, данные показывают, что если и происходит обновление регионального депутатского корпуса, то не за счет притока женщин.

Таблица З. Пол и номер элитной позиции в биографии, 2019 г.

\begin{tabular}{|c|c|c|c|c|}
\hline \multirow{3}{*}{$\begin{array}{l}\text { Номер данной элитной позиции } \\
\text { в биографии }\end{array}$} & \multicolumn{4}{|c|}{ Пол } \\
\hline & \multicolumn{2}{|c|}{ Мужской } & \multicolumn{2}{|c|}{ Женский } \\
\hline & $\mathbf{N}$ & $\%$ & $\mathbf{N}$ & $\%$ \\
\hline $\begin{array}{l}\text { Первый раз занимает эту позицию- } \\
\text { “новичок” В этой должности }\end{array}$ & 238 & 50 & 63 & 66 \\
\hline Второй раз & 108 & 22 & 20 & 21 \\
\hline Третий раз & 69 & 14 & 4 & 4 \\
\hline Четвертый и далее & 67 & 14 & 8 & 9 \\
\hline Всего: & 482 & 100 & 95 & 100 \\
\hline
\end{tabular}

Другая переменная, связанная с характеристиками карьерных траекторий,“предэлитная работа", позволяет определить, какая работа предшествует занятию первой элитной позиции представителем депутатского корпуса. В этом контексте анализ данных показывает, что в большинстве случаев женщины работают на высших иерархических позициях в сфере образования, культуры, здравоохранения и спорта - $28 \%$ (мужчин там только 8\%), почти 18\% женщин рекрутируются в законодательный орган власти через высшие позиции в экономических институциях (мужчины гораздо чаще-49\%). Интересны данные по позициям «помощник депутата, работник аппарата представительного органа федерального уровня" и «руководитель аппарата представительных органов федерального уровня", когда в рассматриваемых группах (позиция "предэлитная работа") женщин и мужчин примерно поровну (в первой группе по 1\% соответственно; во второй группе-3\% мужчин и $4 \%$ женщин).

В целом полученные данные позволяют определить, что наиболее часто представители политической элиты (как мужчины, так и женщины) до обретения депутатского мандата уже занимали высокие позиции в различных профессиональных институциях. Таким образом, происходит лишь их горизонтальное перемещение с одной высокой позиции на другую в рамках элитной общности региона. Если оценивать партийную принадлежность, то большинство женщин-депутатов выдвигаются от правящей партии «Единая Россия", и за последнее десятилетие ситуация с партийной принадлежностью женщин-депутатов кардинально не изменилась. Как писали по итогам исследования 2008 г. А. Е. Чирикова и Н. Ю. Лапина, "Выборочный анализ гендерного состава региональных парламентов, проведенный нами в 20 регионах Российской Федерации, показал, что большинство женщин были избраны от „Единой России“» [там же: 11].

Анализ структурных биографий депутатов-женщин показывает, что чаще всего их рекрутирование в местные парламенты осуществляется через исполнительные ор- 
ганы власти, сферы образования и здравоохранения ${ }^{11}$. По данным Н. Ю. Лапиной и А. Е. Чириковой, именно “успехи, одержанные женщинами в исполнительной власти, стимулировали их продвижение в органы власти представительной" [там же: 20]. Российские исполнительные органы власти осуществляют роль одного из основных каналов по рекрутированию на депутатские позиции. Так, эмпирические данные показывают, что предэлитная активность, понимаемая как сфера деятельности, непосредственно предшествующая первой в биографии элитной должности, у $33 \%$ женщин (и 28\% мужчин) происходила в политико-административной сфере, у $35 \%$ женщин и $55 \%$ мужчин - в хозяйственно-экономических структурах. Что касается других данных, то большинство женщин, представляющих политическую элиту десяти российских регионов, на момент попадания на депутатский пост занимали высшие позиции в сферах образования, культуры, здравоохранения, спорта (для сравнения - только 7 \% мужчин занимали предэлитные позиции в указанных сферах, большинство мужчин-депутатов работали на высших экономических позициях - 49\%). Таким образом, нами определено, что у трети женщин-депутатов профессиональная социализация проходила в социальной сфере, и реже (18\%)на высших позициях в экономических структурах.

Интерес для исследования представляет и "статусный запуск" в элитной карьере женщин-депутатов. Количественные данные в этом смысле имеют методические ограничения, и потому обратимся к индивидуальным биографиям представительниц политической элиты региона. Формализованные индивидуальные биографии, в частности, калининградских женщин-депутатов показывают, что свой профессиональный путь они начинали в социальной сфере, например, в дошкольных и школьных учреждениях. Выступает ли эта профессиональная предыстория основанием для попадания в депутатское кресло? Если немецкий исследователь К. Майер, рассуждая о жизненном пути, замечает важность «эндогенной причинной взаимосвязи", то Г. Рохер обращает внимание на источник контингентности - научающий "опыт" и решения, которые по сути своей ограничивают или расширяют спектр возможных выборов индивида [Блоссфельд, Хъюнинк, 2006: 17]. В этой связи, несмотря на то что количественные данные показывают, что у большинства региональных женщин-депутатов вторичная социализация проходила в институциях социальной сферы, служит ли эта должностная позиция точкой для "статусного запуска", мы не можем ответить, не прибегая к анализу индивидуальных биографий.

Рассмотрение биографий калининградских женщин-депутатов шестого созыва (2016-2021 гг.), имеющих большой опыт работы в институциях социальной сферы, показывает, что при учете контингентности жизненного пути существуют и иные основания для вертикальных и горизонтальных перемещений. Например, случай женщины-депутата О. демонстрирует, что, занимая высокие позиции в органах исполнительной власти и возглавляя министерство социального профиля перед избранием в парламент, представительница политической элиты имела большой номенклатурный опыт, позволивший ей конвертировать его в работу на тех должностях в социальной сфере, которые традиционно занимают женщины. Руководящая

\footnotetext{
${ }^{11}$ Структурно-биографический анализ предполагает изучение структуры элиты на основе биографий ее представителей.
} 
позиция еще в 1980-е годы в городском обкоме комсомола, по нашему мнению, могла стать поворотной точкой в жизненном пути, ибо далее в биографии депутата фиксируются лишь сведения о вертикальном перемещении с городского на региональный уровень управления (в течение десяти дет), и серьезных изменений в профессиональной траектории не наблюдается. После достижения высшей элитной позиции в региональных административных органах власти происходит лишь горизонтальное перемещение депутата внутри властных институций.

Второй случай биографии женщины-депутата В. также показывает, что профессиональная социализация происходила в рамках социальной сферы, в учреждениях образования, но далее случился поворот в биографии, и представительница политической элиты, прежде чем обрести депутатский мандат, длительное время возглавляла образовательное учреждение в структуре силового министерства. В этом случае мы имеем разорванную социализацию и опыт работы не только в социальных, но и военных учреждениях, что неизбежно накладывает отпечаток на социальный бэкграунд кандидата в депутаты.

Третий случай “социальной” биографии представительницы политической элиты демонстрирует "самый чистый» случай карьерного восхождения в рамках образовательных учреждений, когда имелся двадцатилетний опыт работы в дошкольном учреждении, и далее профессиональный опыт конвертировался в депутатскую позицию. Таким образом, даже схематичный анализ биографий политической элиты на предмет того, как связана карьера женщин-депутатов с традиционно упоминаемой в научной литературе социальной сферой как основным каналом рекрутирования на позицию регионального депутата, показывает, что из трех случаев только одна профессиональная биография оказывается примером карьерного восхождения в рамках одной социальной институции (дошкольного учреждения). В целом взаимовлияние и взаимосвязи, неизбежно возникающие в профессиональной сфере, по нашему мнению, необходимо учитывать при оценке карьерных траекторий женщин-депутатов.

Кроме рассмотрения индивидуальных биографий следует обратить внимание и на такой источник информации, как интервью политиков в СМИ. В них часто содержатся оценки, мнения о гендерной ситуации, позволяющие в данном исследовании привлекать такой эмпирический материал в качестве дополнительного. Анализ интервью с представителем калининградской политической элиты показывает, что в дискурсе женщины-депутата не существует проблемы гендерного неравенства, так как, по ее мнению, "пол на работе не важен", но "многие вещи, если говорить, допустим, про власть, женщины немного по-другому воспринимают. Нужно разумное сочетание мужского трезвого ума и женского восприятия каждой проблемы. Так что все зависит от самого человека, а не от пола» ${ }^{12}$.

\section{Образовательные траектории женщин}

Образовательный уровень депутатов считается важной характеристикой при рассмотрении гендерного неравенства в политической элите. В пользу этого говорят многочисленные исследования, в которых образование рассматривается

\footnotetext{
12 Марков И. Председатель калининградской облдумы рассказала, почему пол на работе не важен // Комсомольская правда. 2018. 19 декабря. URL: https://www.kaliningrad.kp.ru/online/news/3333041/ (дата обращения 24.12. 2019).
} 
как пропуск не только в большую политику, но и в политическую элиту. В частности, накопленный образовательный уровень позволяет элите длительное время оставаться особой культурной общностью, а разделяемые ценности, установки и взгляды способствуют укреплению социальных связей и снижению неопределенностей внутри элитных групп [Engelstad, 2018]. Обучение представителей европейской элиты в престижных (часто закрытых) учебных заведениях позволяет утверждать, что часто именно образование играет роль эксклюзивного канала для рекрутирования в политическую и экономическую элиту общества и оказывается способом ее самозакрытия [Hartmann, 2011].

В этой связи возникает вопрос, является ли образование значимым и выталкивающим фактором в российском процессе элитообразования. В условиях нестабильности современного российского общества образование неизбежно влияет на функционирование и устойчивость элиты как социальной общности. Поэтому образовательный статус депутатов в исследовании, наравне с карьерными траекториями, рассматривается как часть жизненного пути индивида. Однако в этих условиях важно обратить внимание на то, какую роль в вертикальных перемещениях региональной элиты играют образовательные институции. Каков образовательный профиль получаемого образования исследуемых нами депутатов и как это влияет на однородность социально-структурных характеристик политической элиты?

Эмпирические данные по первому высшему образованию в гендерном разрезе показывают, что основные образовательные профили у женщин и мужчин различаются. Среди женщин-депутатов преобладают те, кто имеет диплом медицинского (или ветеринарного) (18\%), гуманитарного (28\%) и экономического вузов (12\%). В случае первого высшего образования, которое имеют мужчины-депутаты, характерен технологический уклон, когда преобладание специалистов с дипломами технического вуза очевидно (более $40 \%$ ). Вторые позиции среди мужчиндепутатов занимают экономисты (15\%), далее идут выпускники военных вузов (13\%). Технологизация высшего образования региональной элиты не является новой характеристикой в ее облике. Более ранние наши исследования показывают, что в среде политико-административной элиты регионов в 2005-2007 гг. и в 2012 г. также преобладали "технари" (и далее шли экономисты и силовики), и это было в большей степени наследием советской структуры высшего образования. Мы зафиксировали, что в 2000-е годы в политико-административной элите регионов были представлены те, кто имел номенклатурный опыт работы ${ }^{13}$. Исследования О. Крыштановской также показывают, что $82 \%$ представителей региональной элиты (это не только депутаты) имели номенклатурное прошлое [Крыштановская, 1995]. Однако в более поздний период, начиная с 2000-х годов, доля депутатов, имеющих номенклатурный опыт, постепенно уменьшалась, но не исчезла вовсе. Эмпирические данные 2019 г. позволяют утверждать, что наиболее "номенклатурным" в исследовании оказался парламент Костромской

\footnotetext{
${ }^{13}$ См.: Дука А. В., Быстрова А. С., Колесник Н. В., Невский А.В., Тев Д. Б. (2008) Российские региональные элиты: инновационный потенциал в контексте глобализации //Елисеева И.И. (ред.) Глобализация в российском обществе. СПб.: Нестор-История. С. 99-242, Быстрова А. С., Даугавет А. Б., Дука А. В., Колесник Н. В., Невский А. В., Тев Д. Б. Региональная политическая элита: бассейн рекрутирования и карьера // Власть и элиты. 2020. Т. 7. № 1. С. 76 -122.
} 
области - $20 \%$, и в меньшей степени - народное собрание Республики Дагестан (6\%). В среднем по выборке доля депутатов-номенклатурщиков составляет $12 \%$.

При обращении к типу второго высшего образования складывается иная картина (см. табл. 4). Второе высшее образование представители региональной элиты получают уже в более взрослом возрасте, занимая элитные позиции во властных институциях. Наиболее часто второе высшее образование связано с экономическими, управленческо-политическими и юридическими специальностями. Как и в целом по стране, в элитной региональной общности наблюдается рост выпускников-экономистов, управленцев и юристов. Эти процессы синхронизированы среди мужчин-депутатов и женщин-депутатов, когда фиксируется примерно одинаковое количество управленцев (более $40 \%$ ), экономистов (по 15\%), юристов (около 20\%).

Таблица 4. Пол и второе высшее образование, 2019 г. (\%)

\begin{tabular}{|l|c|c|}
\hline \multirow{2}{*}{ Тип высшего образования } & \multicolumn{2}{|c|}{ Пол } \\
\cline { 2 - 3 } & Мужской & Женский \\
\hline Финансово-экономическое & 15 & 15 \\
\hline Управленческо-политическое & 44 & 48 \\
\hline Гуманитарное & 2 & 13 \\
\hline Техническое & 6 & 0 \\
\hline Юридическое & 20 & 17 \\
\hline Военное & 9 & 0 \\
\hline Медицинское и ветеринарное & 2 & 2 \\
\hline Другое & 2 & 5 \\
\hline Всего & 100 & 100 \\
\hline
\end{tabular}

В ходе исследования мы зафиксировали такой показатель, как эндогенность, когда определялось совпадение региона нахождения парламента и места получения высшего образования. Ситуация по десяти регионам показывает, что в основном преобладает эндогенная элита: представители политической элиты получают высшее образование в регионе избрания депутатом местной легислатуры. При этом женщины-депутаты на фоне мужчин-депутатов более мобильны и чаще получают высшее образование за пределами региона - $68 \%$ и $61 \%$ соответственно.

Дополнительное образование и наличие ученой степени оказываются важными элементами образовательного капитала политической элиты десяти российских регионов. Полученные эмпирические данные показывают, что почти $30 \%$ депутатов имеют дипломы кандидата наук и защищали диссертации по экономическим, юридическим и техническим специальностям. Эта тенденция весьма устойчива. Так, данные 2011-2016 гг. показывают, что представители политикоадминистративной элиты российских регионов защищают кандидатские и докторские диссертации по экономическим направлениям [Колесник, 2019]. Интересен факт, что аналогичный образовательный порядок наблюдается и среди феде- 
ральной элиты. Так, $45 \%$ ее представителей имеют ученую степень доктора (199 докторов наук) или кандидата наук (375 кандидатов наук). Согласно вторичным данным, представители федеральной элиты чаще всего защищают диссертации по экономическим (217 человек) и юридическим (125 человек) наукам ${ }^{14}$.

Если рассматривать данные через призму гендерной оптики, то можно заметить, что среди мужчин и женщин наблюдается равенство тех, кто имеет кандидатскую степень (по $27 \%$ ), однако среди мужчин чуть меньше обладателей степени доктора наук, нежели среди женщин (7 \% против 13\%) (см. табл. 5). Расчеты в абсолютных величинах показывают, что в среднем остепененных среди мужчин-депутатов в пять раз больше, чем среди женщин-депутатов (168 против 30).

Таблица 5. Пол и наличие ученой степени, 2019 г. (\%)

\begin{tabular}{|l|c|c|}
\hline \multirow{2}{*}{\multicolumn{1}{|c|}{ Ученая степень }} & \multicolumn{2}{|c|}{ Пол } \\
\cline { 2 - 3 } & Мужской & Женский \\
\hline Наличие ученой степени & 69 & 71 \\
\hline Отсутствие ученой степени & 31 & 29 \\
\hline Всего & 100 & 100 \\
\hline
\end{tabular}

В большинстве случаев женщины становятся обладателями диплома кандидата наук сразу после получения высшего образования, что выглядит естественным в рамках образовательной траектории. Депутаты-мужчины, напротив, защищают кандидатские диссертации гораздо позже, после 40 лет, что становится, скорее всего, важным атрибутом продолжающейся профессиональной карьеры. Таким образом, анализ образовательных траекторий парламентской элиты десяти российских регионов показывает, что в целом женщины-депутаты представляют собой высокообразованную общность. Высшее образование женщины-депутаты чаще всего получают в нерегиональных вузах, в отличие от мужчин-депутатов, которые выбирают вузы по принципу “где родился там и пригодился". Что касается выбора специальностей для первого высшего образования, то здесь существенных различий не наблюдается: как мужчины, так и женщины чаще всего обучаются на факультетах "управления", "экономики" и «права".

Полученные данные фиксируют, что в регионах отсутствуют устойчивые пулы "элитных" вузов, в которых бы обучалось большинство представителей политической элиты региона и которые бы оказывали определенное влияние на характер взаимодействия внутриэлитной общности. Следует заметить, что наличие диплома о высшем образовании того или вуза не всегда эквивалентно качеству образования и тем более имеет малое отношение к эксклюзивности социального рекрутирования посредством элитного образования. В этой ситуации роль Вытягивающих факторов берут на себя другие формальные и неформальные институции, благодаря которым те или кандидаты и обретают депутатские мандаты.

\footnotetext{
${ }_{14}$ Рейтинги вузов по образованию представителей элиты государственного управления России-2014. Национальный рейтинг университетов Интерфакс // Финансовый университет при Правительстве РФ. 2014. URL: http://www.fa.ru/ NewsFiles/2014-07-01-vuzy-dlya-elit/GovElite.pdf (дата обращения 23.08.2021).
} 


\section{Заключение}

Исследование гендерного неравенства в региональной политической элите в современной России позволило определить мозаичность в депутатском корпусе с точки зрения представленности мужчин и женщин. Полученные данные дают возможность утверждать, что представители политической элиты - как мужчины, так и женщины - до обретения депутатского мандата уже занимали высокие позиции в различных профессиональных институциях, и происходило лишь их горизонтальное перемещение с одной элитной позиции на другую. Анализ структурных биографий женщин-депутатов показывает, что чаще всего рекрутирование в региональные парламенты осуществляется через исполнительные органы власти, сферы образования и здравоохранения. Среди мужчин и женщин наблюдается асимметрия при вхождении в элитную должность в зависимости от возраста: женщины гораздо позже впервые занимают элитную позицию, чем мужчины.

В десяти рассмотренных российских регионах преобладает эндогенная политическая элита, когда ее представители получают высшее образование в месте избрания депутатом местной легислатуры. Эмпирические данные по первому высшему образованию в гендерном разрезе позволяют сделать вывод, что основной образовательный профиль у женщин и мужчин различается. Среди женщин-депутатов по первому высшему образованию преобладают гуманитарии, медики, экономисты, среди мужчин - технические специалисты, экономисты, военные. Далее определено, что второе высшее образование представители региональной элиты чаще всего получают в более взрослом состоянии, уже занимая элитные позиции во властных институциях. Зачастую второе высшее образование связано с экономическими, управленческо-политическими и юридическими специальностями.

Количественный анализ биографий политической элиты показывает, что женщины-депутаты обычно рекрутируются из административной элиты, занимая высшие позиции в институциях социальной сферы. Введение же дополнительных качественных данных показало, что из трех случаев только одна профессиональная биография может быть примером карьерного восхождения в рамках социальной институции (сферы образования), и поэтому взаимовлияния и взаимосвязи, неизбежно возникающие в профессиональной сфере, необходимо учитывать при оценке карьерных траекторий женщин-депутатов.

Таким образом, рассмотренные региональные случаи гендерной представленности в легислатурах современной России показали, что даже если в парламенте и наблюдается гендерный паритет, то чаще всего элита обновляется по принципу замещения, когда обновления имеют имитационный характер [Best, Higley, 2018]). Эмпирические данные свидетельствуют, что политическая элита активно профессионализируется, переплетается с административной элитой и оказывается закрытой для притока новых персон на позиции не только в региональных, но и в столичных парламентах. В этой связи для объективного анализа необходимо вовлекать не только данные по социальной структуре парламентов, но и учитывать экономический и политический профили рассматриваемых регионов, вводить дополнительные индикаторы для измерения гендерного профиля российской власти.

В целом количественный анализ данных гендерной структуры десяти российских региональных парламентов не до конца проясняет, каковы причины сущест- 
вующей асимметрии в представленности мужчин и женщин во властных структурах, но позволяет выявить важные тенденции и определить направления для дальнейших дискуссий. Например, по-прежнему остаются открытыми вопросы о связи гендерного равенства с демократией и коррупцией: существуют ли они? Данные международных проектов показывают, что не только в государствах со старыми демократиями, но и в развивающихся странах имеются примеры гендерного паритета в национальных парламентах. Так, исследование Всемирного банка в начале 2000-х годов по 150 странам Европы, Африки и Азии продемонстрировало, что женщины более надежны и менее подвержены коррупции. Следует также отметить, что, хотя корреляция между вовлечением женщин в общественную жизнь и более низким уровнем коррупции не оспаривается, вторая волна исследований привела к уточнениям первоначальных результатов и поставила под сомнение направление причинно-следственной связи ${ }^{15}$. "Например, может возникнуть вопрос, являются ли женщины по своей сути менее коррумпированными, или именно демократия является основным условием того, что более широкое участие женщин в правительстве связано с меньшей коррупцией. Фактически страны, где женщины более представлены в правительстве, как правило, также имеют более либеральные демократические институты, обеспечивающие более эффективные проверки фактов коррупции, а также „более справедливые системы“, способствующие гендерному равенству» ${ }^{16}$.

\section{Список литература (References)}

Айвазова С.Г. Гендерные особенности политического поведения россиян в контексте избирательного цикла парламентских и президентских выборов 20112012 гг. // Женщина в российском обществе. 2012. № 3. С. 3-11.

Aivazova S. G. (2012) Gender Characteristics of the Political Behavior of Russians in the Context of the Electoral Cycle of the Parliamentary and Presidential Elections of 2011-2012. Woman in Russian Society. No. 3. P. 3-11. (In Russ.)

Блоссфельд Х.-П., Хъюнинк И. Исследование жизненных путей в социальных науках: темы, концепции, методы и проблемы // Журнал социологии и социальной антропологии. 2006. T. IX. № 1. С. 15-44.

Blossfeld H.-P., Huinink I. (2006) Study of Life Paths in the Social Sciences: Topics, Concepts, Methods and Problems. Journal of Sociology and Social Anthropology. Vol. IX. No. 1. P. 15-44. (In Russ.)

Гнедаш А. А. Политико-административные элиты постсоветской России: гендерное измерение (по материалам экспертного опроса в Краснодарском крае) // Новые направления политической науки: гендерная политология, институциональная политология, политическая экономия, социальная политика. Москва: РАПН, РОССПЭН, 2007. С. 258-274.

\footnotetext{
${ }^{15}$ Gender, Equality and Corruption: What Are the Linkages? (Policy Brief) //Transparency International. 2014. January. URL: https://www.transparency.org/whatwedo/publication/policy_position_01_2014_gender_equality_and_corruption_what_ are_the_linkage (дата обращения: 21.08.2021).

${ }^{16}$ Там же.
} 
Gnedash A. A. (2007) Political and Administrative Elites of Post-Soviet Russia: Gender Dimension (Based on an Expert Survey in Krasnodar Region) In: New Directions in Political Science: Gender Political Science, Institutional Political Science, Political Economy, Social policy. Moscow: Russian Political Science Association, ROSSPEN. P. 258-274. (In Russ.)

Дука А. В. Вариантность социологии элит // Журнал социологии и социальной антропологии. 2015. Том XVIII. № 4. С. 5-23.

Duka A. V. (2015) Variation of the Sociology of Wlites. Journal of Sociology and Social Anthropology. Vol. XVIII. No. 4. P. 5-23. (In Russ.)

Здравомыслова Е. А., Темкина А. А. Государственное конструирование гендера в советском обществе // Журнал исследований социальной политики. 2003. Т. 1. № 3-4. C. $299-322$.

Zdravomyslova E. A., Temkina A. A. (2003) State Construction of Gender in Soviet Society. Journal of Social Policy Research. Vol. 1. No. 3-4. P. 299-322. (In Russ.)

Здравомыслова Е. А., Темкина А. А. Патриархат и женская власть // Российский гендерный порядок: социологический подход / под ред. Е. Здравомысловой и А. Темкиной. СПб. : Европейский университет в Санкт-Петербурге, 2007. С. 68-95.

Zdravomyslova E. A, Temkina A. A. (2007) Patriarchate and Women's Power. In: E. Zdravomyslova, A. Temkina (eds.) Russian Gender Order: Sociological Approach. St. Petersburg: European University in Saint Petersburg. P. 68-95. (In Russ.)

Колесник Н. В. Гендерные распределения в региональной элите (северо-запад и юг России) // Политическая экспертиза: Политекс. 2009. № 5. С. 72-87.

Kolesnik N. V. (2009) Gender Distributions in the Regional Elite (North-West and South of Russia). Political Expertise: Polytex. No. 5. P. 72-87. (In Russ.)

Колесник Н. В. Образовательные траектории российской элиты: региональная проекция // Мир России. 2019. Т. 28. № 4. С. 30-48.

Kolesnik N. V. (2019) Educational Trajectories of the Russian Elite: Regional Projection. Universe of Russia. V. 28. No. 4. P. 30-48. (In Russ.)

Крыштановская О. Трансформация старой номенклатуры в новую российскую элиту // Общественные науки и современность. 1995. № 1. С. 51-65.

Kryshtanovskaya O. (1995) Transformation of the Old Nomenclature into a New Russian Elite. Social Sciences and Modernity. No. 1. P. 51-65. (In Russ.)

Овчарова О.Г. Гендерная асимметрия в сфере политики: поиски институционального решения проблемы // Вестник Саратовской государственной академии права. 2007. № 5 (57). С. 214-219.

Ovcharova O.G. (2007) Gender Asymmetry in Politics: The Search for an Institutional Solution to the Problem. Bulletin of the Saratov State Academy of Law. No. 5 (57). P. 214-219. (In Russ.)

Пушкарева Н. Л. Где больше власти - там меньше женщин (гендерная экспертиза законодательства и текущей законотворческой деятельности высших органов 
власти РФ 1991-2006 гг.) // Научные ведомости Белгородского государственного университета. Серия: История. Политология. 2008. № 1. С. 117-127.

Pushkareva N. L. (2008) Where There Is More Power, There Are Fewer Women (Gender Expertise of Legislation and Current Legislative Activity of the Highest Authorities of the Russian Federation 1991-2006). Scientific Reports of Belgorod State University. Series: History. Political Science. No. 1. P. 117-127. (In Russ.)

Середа М. В. Женщины как субъект неотрадиционалистской гендерной политики //Женщина в российском обществе. 2011. №3. С. 94-98.

Sereda M. V. (2011) Women as a Subject of Neotraditional Gender Policy. Woman in Russian Society. No. 3. P. 94-98. (In Russ.)

Силласте Г. Женские элиты России и их особенности // Общественные науки и современность. 1994. № 1. С. 112-121.

Sillaste G. (1994) Female Elites of Russia and Their Features. Social Sciences and Modernity. No. 1. P. 112-121. (In Russ.)

Тартаковская И.Н. Воспроизводство гендерного порядка через карьерные стратегии: попытка интерсекционального анализа // Социологические исследования. 2015. № 5. C. 84-93.

Tartakovskaya I. N. (2015) Reproduction of Gender Order through Career Strategies: An Attempt at Intersectional Analysis. Sociological Studies. No. 5. P. 84-93. (In Russ.)

Тартаковская И. Н. Женственность прекарности // Интеракция. Интервью. Интерпретация. 2017. № 14. С. 45-53.

Tartakovskaya I. N. (2017) Femininity of Precarity. Interaction. Interview. Interpretation. No. 14. P. 45-53. (In Russ.)

Чирикова А. Е., Лапина Н. Ю. Женщина на высших этажах власти. Российские практики и французский опыт. М.: Институт социологии РАН, 2009.

Chirikova A. E., Lapina N. Yu. (2009) Woman on the Highest Floors of Government. Russian Practices and French Experience. Moscow: Institute of Sociology RAS. (In Russ.)

Шведова Н. А. Гендерная стратегия как фактор политической культуры / Создание институциональных структур для соблюдения принципа гендерного равенства в России. М.: Миг, 2003.

Shvedova N. A. (2003) Gender Strategy as a Factor of Political Culture. In: Creation of Institutional Structures for Observing the Principle of Gender Equality in Russia. Moscow: Mig Publishing House. (In Russ.)

Фомичева О.А. Особенности конституционного правового статуса депутатов регионального парламента // Известия Тульского государственного университета. Экономические и юридические науки. 2014. Вып. 3. № 2. С. 231-242.

Fomicheva O. A. (2014) Features of the Constitutional Legal Status of Deputies of the Regional Parliament. Bulletin of the Tula State University. Economic and Legal Sciences. Vol. 3. No. 2. P. 231-242. (In Russ.)

Хасбулатова О.А. Гендерный подход как технология повышения эффективности кадровой политики // Женщина в российском обществе. 2014. № 4 (73). С. 3-10. 
Khasbulatova O. A. (2014) Gender Approach as a Technology to Improve the Effectiveness of Personnel Policy. Woman in Russian Society. No. 4 (73). P. 3-10. (In Russ.)

Best H., Higley J. (2018) Introduction. In: H. Best, J. Higley (eds.) The Palgrave Handbook of Political Elites. London: Palgrave Macmillan. P. 1-6.

Engelstad F. (2018) Models of Elite Integration. In: H. Best, J. Higley (eds.) The Palgrave Handbook of Political Elites. London: Palgrave Macmillan. P. 53-68.

Hartmann M. (2011) Elites and Power Structure. In: Immerfall S., Therborn G. (eds.) Handbook of European Societies: Social Transformations in the $21^{\text {st }}$ Century. New York, NY: Springer. P. 291-323.

Inglehart R., Norris P. (2010) Rising Tide. Gender Equality and Cultural Change Around the World. Cambridge, MA: Cambridge University Press. https://doi.org/10.1017/ CB09780511550362.

Norris P., Lovenduski J. (2004) Political Recruitment: Gender, Race, and Class in the British Parliament. Cambridge, MA: Cambridge University Press. 